\title{
Graphite/NiO/Ni Electrode for Electro-oxidation of the Remazol Black 5 Dye
}

\author{
Ni Made Wiratini ${ }^{1,2, *}$, T. Triyono ${ }^{1}$, Wega Trisunaryanti ${ }^{1}$, Agus Kuncaka ${ }^{1}$ \\ ${ }^{1}$ Department of Chemistry, Universitas Gadjah Mada, Yogyakarta, Indonesia. \\ ${ }^{2}$ Department of Chemistry, Universitas Pendidikan Ganesha, Singaraja, Indonesia.
}

Received: 9th July 2021; Revised: $9^{\text {th }}$ September 2021; Accepted: $10^{\text {th }}$ September 2021 Available online: $12^{\text {nd }}$ September 2021; Published regularly: December 2021

\section{Abstract}

Graphite/NiO/Ni electrode had been fabricated for the electro-oxidation of remazol black 5 dye. The electrode was synthesized by electrodeposition method. Electro-oxidation of $100 \mathrm{ppm}$ remazol black 5 dye was carried out at various concentrations of $\mathrm{NaCl}, 0.025 ; 0.05 ; 0.1 ; 0.25$; and $0.5 \mathrm{M}$, variations in electro-oxidation time were 15 , 30, 45, and 60 minutes, and $\mathrm{pH}$ variations were 4,6 , and 8 . Cyclic voltammetry test revealed that graphite/NiO/Ni electrode had higher electrocatalytic capability compared to graphite electrode. The X-ray diffraction (XRD) patterns showed the decreasing value of $2 \theta$ from $44.6^{\circ}$ for $\mathrm{Ni}$ to $43.5^{\circ}$ for NiO. Scanning Electron Microscopy-Energy Dispersive X-ray (SEM-EDX) showed that $\mathrm{NiO} / \mathrm{Ni}$ deposited on the graphite surface in the form of solid grains and cracks, FTIR showed that $\delta(\mathrm{Ni}-\mathrm{O})$ bond appeared at $582-511 \mathrm{~cm}^{-1}$. The decolorization efficiency of remazol black 5 for graphite/NiO/Ni electrode was $100 \%$ for 45 minutes of the electro-oxidation process, while the decolorization efficiency of remazol black 5 for graphite electrode was $99.74 \%$ for 60 minutes of the electro-oxidation process.

Copyright (C 2021 by Authors, Published by BCREC Group. This is an open access article under the CC BY-SA License (https://creativecommons.org/licenses/by-sa/4.0).

Keywords: graphite/NiO/Ni; electro-oxidation; remazol black 5 dye; textile waste

How to Cite: N.M. Wiratini, T. Triyono, W. Trisunaryanti, A. Kuncaka (2021). Graphite/NiO/Ni Electrode for Electro-oxidation of the Remazol Black 5 Dye. Bulletin of Chemical Reaction Engineering \& Catalysis, 16(4), 847856 (doi:10.9767/bcrec.16.4.11702.847-856)

Permalink/DOI: https://doi.org/10.9767/bcrec.16.4.11702.847-856

\section{Introduction}

Synthetic dyes are widely used in the textile industry, especially in the textile dyeing process. Textile industry activities have a negative impact on aquatic ecosystems. The negative impact is colored liquid waste that comes from the dyeing process. Most of the liquid waste is very stable, resistant to chemical reagent reactions, very difficult to decompose, toxic, and carcinogenic [1]. The synthetic dyes, which are used for textile coloring are remazol black 5, remazol brilliant orange $3 \mathrm{R}$, remazol golden yellow, and

\footnotetext{
* Corresponding Author.

Email: ni.made.wiratini@mail.ugm.ac.id (N.M. Wiratini); Telp: +62 85237465122
}

remazol red. The concentration of river water pollution due to textile waste reaches $10-15 \%$ $(\mathrm{m} / \mathrm{v})$ and $50 \%$ of the textile waste contains remazol black 5 compounds [2]. Remazol black 5 is an azo group compound $(-\mathrm{N}=\mathrm{N})$ and a sulfonate $\left(-\mathrm{SO}_{3}-\right)$ [3]. Remazol black 5 dye waste requires effective and efficient handling so that it does not cause environmental pollution.

Various efforts have been made to reduce textile waste pollution, such as coagulation and flocculation to treat batik waste [4], decolorization and biodegradation of remazol reactive dyes by Clostridium species [5], methylene blue adsorption by silica gel from coal fly ash [6], electrochemical oxidation of methylene blue by graphene-modified electrodes [7]. The disad- 
vantages of chemical coagulation, adsorption, and membrane filtration methods are expensive and there are residual adsorbents or coagulants [8]. Azo dyes are resistant to bacterial and biological activity, and the degradation process takes a long time. Therefore, it is necessary to develop alternative technologies that are able to degrade dyes effectively and efficiently [9].

Electrochemical oxidation or electrooxidation is a textile wastewater treatment technology. This technology attracts attention because it has high efficiency, high degradation speed, easy operation, low cost, does not require a catalyst separation process, does not produce secondary pollutants, and is environmentally friendly [10-15]. Electro-oxidation is a process that produces hydroxyl radicals $(\cdot \mathrm{OH})$. Hydroxyl radicals are highly oxidizing species. They can cause the mineralization of organic matter into carbon dioxide, water, and inorganic ions [16]. The performance of the electro-oxidation process depends on the electrode material, the characteristic/amount of electrolyte, and $\mathrm{pH}$ [17].

Various types of electrodes have been used for the electro-oxidation of various dye wastes. Each electrode produces a different efficiency of organic pollutant degradation. The expanded graphite diamond (EG/Diamond) anode electrode has removed $80 \%$ of anthraquinonic dye and the expanded graphite (EG) electrode has removed $66 \%$ of anthraquinonic dye, at a current of $20 \mathrm{~mA} / \mathrm{cm}^{2}, 0.1 \mathrm{M} \mathrm{Na}_{2} \mathrm{SO}_{4}$ for 4 hours. However, with chlorine mediated electrooxidation ( $\mathrm{NaCl}$ as the supporting electrolyte), the decolorization is faster, i.e. more than $98 \%$ decolorization in 25 minutes [18]. Pt anode electrode has degraded $96 \%$ reactive blue 109 (1000 $\mathrm{mg} / \mathrm{L}$ ) at $\mathrm{pH} 4$, current (I) $20 \mathrm{~mA} / \mathrm{cm}^{2}, 0.1$ $\mathrm{M} \mathrm{NaCl}$ [19]. Pt/MnO 2 anode electrode has degraded $90 \%$ methylene blue $(40 \mathrm{mg} / \mathrm{L})$ at $\mathrm{pH} 8$, current (I) $7 \mathrm{~mA} / \mathrm{cm}^{2} ; 0.05 \mathrm{M} \mathrm{Na}_{2} \mathrm{SO}_{4}$ for 2 hours [20]. The anode electrode $\mathrm{Ti} / \mathrm{Ta}_{2} \mathrm{O}_{5} / \mathrm{SnO}_{2}$ has degraded $95 \%$ methylene blue $(0.025 \mathrm{mM})$ with a current (I) of $9.1 \mathrm{~mA} / \mathrm{cm}^{2}, 0.1 \mathrm{M} \mathrm{NaSO}_{4}$ for 3 hours [21]. Graphite electrodes on electrofenton have degraded $99.2 \%$ rhodamine $\mathrm{B}$ with the addition of $10 \mathrm{mg} / \mathrm{L} \mathrm{Fe}^{2+}$ catalyst, $\mathrm{pH} \mathrm{3}$, voltage $8 \mathrm{~V}$, for 2 hours [22].

Graphite is often used as an anode for textile dye electro-oxidation because it is relatively inexpensive, intensively used on a laboratory scale for investigation of new processes, and gives satisfactory results. However, graphite electrodes also have weaknesses, such as low oxidation activity of organic compounds, high average corrosion rate, and low mineralization efficiency [21]. The efficiency of the electrooxidation process is highly dependent on the electrode material, dye concentration, and other operating parameters, such as $\mathrm{pH}$; concentration and type of electrolyte solution; and the duration of the electro-oxidation process. Nickel oxide ( $\mathrm{NiO}$ ) and nickel $(\mathrm{Ni})$ are anode materials for the oxidation of organic compounds in alkaline media [23]. $\mathrm{NiO}$ is a metal oxide that is a semiconductor, the most promising electrocatalyst, more often used compared to $\mathrm{Pt}$ or $\mathrm{RuO}_{2}$, environmentally friendly, and inexpensive [24]. Ni is used as an electrocatalyst for anodic and cathodic reactions in the organic synthesis and electrolysis of water [25].

The combination of transition metal oxides on graphite is a potential technology to increase catalytic activity [11]. The combination of transition metal oxides on graphite can overcome the disadvantages of graphite electrodes, so it can increase the efficiency of dye degradation. The combination of $\mathrm{NiO} / \mathrm{Ni}$ on graphite electrodes is carried out by electrodeposition. This study examines graphite electrodes and graphite/NiO/Ni electrodes in the electrodegradation of remazol black dye 5. The effect of the experimental conditions studied is the concentration of $\mathrm{NaCl}$ electrolyte solution, the electrooxidation time process, and the $\mathrm{pH}$.

\section{Materials and Methods}

\subsection{Materials}

The materials used for the investigation are $\mathrm{NiSO}_{4} .6 \mathrm{H}_{2} \mathrm{O}$ (Sigma Aldrich, >98\%), $\mathrm{H}_{2} \mathrm{O}_{2}$ (Merck, 30\%), TMOS (SCIP, 99\%), H3BO3 (Merck, $\geq 99.5 \%$ ), ethanol (Merck, 99.7\%), NaCl (Merck, $\geq 99.5 \%$ ), $\mathrm{H}_{2} \mathrm{SO}_{4}$ (Merck, 98\%), graphite electrode (SCIP, 99.9\%), and remazol black 5 (Sigma Aldrich, $\geq 50 \%$ ).

\subsection{Preparation of the Graphite Electrode}

Graphite electrodes were immersed in 50 $\mathrm{mL}$ of $0.003 \mathrm{M} \mathrm{H}_{2} \mathrm{SO}_{4}$ and $30 \% \mathrm{H}_{2} \mathrm{O}_{2}$ in a ratio of 1:4 for 15 minutes [2]. The graphite electrodes were heated in the oven at $110{ }^{\circ} \mathrm{C}$ for 2 hours. Then, the graphite electrodes were cooled in a desiccator and weighed using a digital analytical balance. The graphite electrode was characterized by XRD-6000 and cyclic voltammetric Autolab type III Metrohm. Cyclic voltammetric characterization was carried out at a scan rate of $10 \mathrm{mV} / \mathrm{s}$ in a $0.1 \mathrm{M} \mathrm{NaCl}$ solution, $\mathrm{Ag} / \mathrm{AgCl}$ as a reference electrode, $\mathrm{Pt}$ as a counter electrode, and graphite as a working electrode. 


\subsection{Graphite/NiO/Ni Electrode Synthesis}

Graphite/NiO/Ni electrode was synthesized by the electrodeposition method, a modification of the research conducted by Zhang et al. [26]. A total of $100 \mathrm{~mL}$ of $\mathrm{Ni}$ deposition solution $(0.2$ $\mathrm{M} \mathrm{NiSO} 4.6 \mathrm{H}_{2} \mathrm{O}$ and $0.4 \mathrm{M} \mathrm{H}_{3} \mathrm{BO}_{3}$ ) was stirred for 10 minutes at $100 \mathrm{rpm}$. Electrodeposition was carried out at 9 volts for 120 minutes. The graphite/ $\mathrm{NiO} / \mathrm{Ni}$ electrode formed was heated at $400{ }^{\circ} \mathrm{C}$ for 2 hours and weighed on an analytical balance. Graphite/NiO/Ni electrodes were characterized by XRD-6000 SHIMADZU. The graphite/NiO/Ni electrode morphology was characterized by electron microscopy (SEMEDX, FEI Inspect S50). Its chemical structure was proven by infrared spectroscopy Fourier transformation (FT-IR). Characterization of graphite/NiO/Ni with cyclic voltammetric $\mathrm{Au}$ tolab type III Metrohm was carried out at a scan rate of $10 \mathrm{mV} / \mathrm{s}$ in $0.1 \mathrm{M} \mathrm{NaCl}$ solution, $\mathrm{Ag} / \mathrm{AgCl}$ as a reference electrode, $\mathrm{Pt}$ as a counter electrode, and graphite/NiO/Ni as a working electrode.

\subsection{Electro-oxidation of Remazol Black 5 Dye}

The process of electro-oxidation of remazol black 5 dye was carried out by varying the concentration of sodium chloride solution, electrooxidation time, and $\mathrm{pH}$. A schematic diagram of remazol black 5 electro-oxidation with graphite electrodes and graphite/ $\mathrm{NiO} / \mathrm{Ni}$ electrodes is shown in Figure 1. Graphite electrodes were used as cathodes and graphite/NiO/Ni electrodes were used as anodes. Electrodes were connected to a DC of 9 volts. The distance between the anode and cathode electrodes was 1 $\mathrm{cm}$.

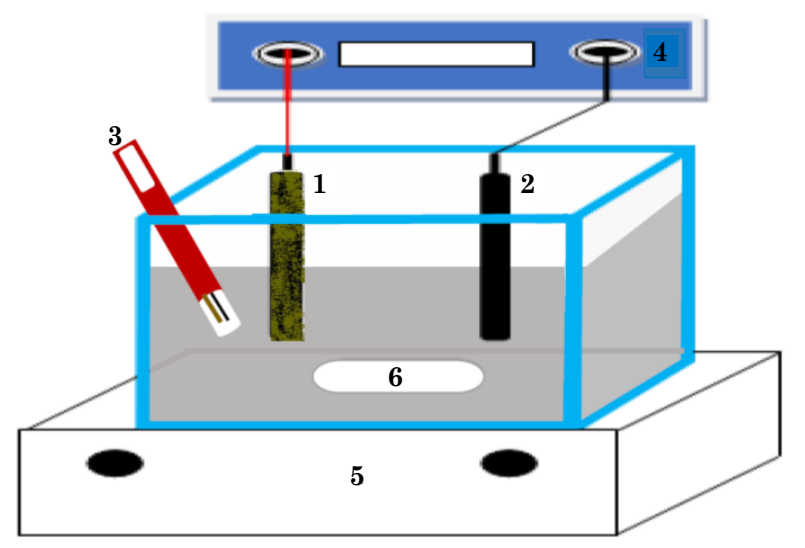

Figure 1. The electro-oxidation schematic cell of remazol black 5 with (1) anode (graphite/NiO/Ni or graphite), (2) cathode (graphite), (3) pH meter, (4) DC power supply, (5) magnetic stirrer, and (6) magnet.
2.4.1 Electro-oxidation of Remazol Black 5 Dye at Various Concentration of $\mathrm{NaCl}$ Solution

Electro-oxidation of remazol black 5 dye was carried out at various concentrations of sodium chloride solution. A total of $75 \mathrm{~mL}$ of $100 \mathrm{ppm}$ of remazol black 5 dye was added to $50 \mathrm{~mL}$ of $\mathrm{NaCl}$ solution with a concentration variation of $0.025 ; 0.05 ; 0.1 ; 0.25$; and $0.5 \mathrm{M}$ respectively. Electro-oxidation was carried out at 9 volts for 30 minutes. The results of the electro-oxidation were filtered and measured by a UV-vis spectrophotometer.

2.4.2 Electro-oxidation of Remazol Black 5 Dye at Various Electro-oxidation Time

Electro-oxidation of remazol black 5 dye was also carried out at various times. A total of 75 $\mathrm{mL}$ of $100 \mathrm{ppm}$ of remazol black 5 dye was added to $50 \mathrm{~mL}$ of $0.025 \mathrm{M} \mathrm{NaCl}$ solution. The electro-oxidation was carried out at 9 volts for 15 , 30,45 , and 60 minutes respectively. The results of the electro-oxidation were filtered and measured using a UV-vis spectrophotometer.

\subsubsection{Electro-oxidation of Remazol Black 5 Dye at Various $\mathrm{pH}$}

Electro-oxidation of remazol black 5 dye was carried out at various $\mathrm{pH}$. A total of $75 \mathrm{~mL}$ of $100 \mathrm{ppm}$ of remazol black 5 dye at $\mathrm{pH}$ of $2,4,6$, and 8 respectively was added with $50 \mathrm{~mL}$ of $0.025 \mathrm{M} \mathrm{NaCl}$ solution. Electro-oxidation was carried out using 9 volts DC for 30 minutes. The results of electro-oxidation were filtered and measured using a UV-vis spectrophotometer.

Determination of the maximum wavelength of remazol black 5 dye was carried out by measuring the absorbance of remazol black 5 dye at the wavelength of $200-800 \mathrm{~nm}$ by UVvis spectrophotometer. The measurement results showed the maximum wavelength of remazol black 5 dye is $595 \mathrm{~nm}$. Therefore, measurement of the results of electro-oxidation by UV-vis spectrophotometer was carried out at $595 \mathrm{~nm}$ wavelength. The decolorization efficiency in the electro-oxidation of remazol black 5 dye was calculated by the equation:

$$
\% E=\frac{A_{i}-A_{f}}{A_{i}} \times 100
$$

where $A_{i}$ is the absorbance value of remazol black 5 dye solution before electro-oxidation and $A_{f}$ is the absorbance value of remazol black 5 dye solution after electro-oxidation. 


\section{Results and Discussion}

3.1 Characterization of Graphite and Graphite/ $\mathrm{NiO} / \mathrm{Ni}$ Electrodes

The gravimetric method was carried out to prove that $\mathrm{NiO} / \mathrm{Ni}$ was already attached to the graphite electrode. The results showed that the mass of the graphite electrode was 5.721 grams before electrodeposition and 6.103 grams after the electrodeposition process. The addition of

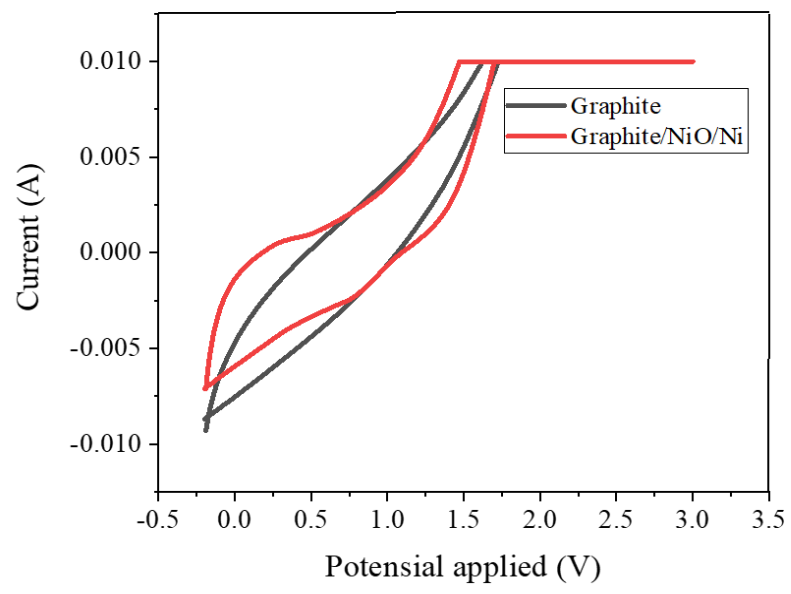

Figure 2. Voltamogram of graphite and graphite/ $\mathrm{NiO} / \mathrm{Ni}$ electrodes at $0.1 \mathrm{M} \mathrm{NaCl}$ at a 10 $\mathrm{mV} . \mathrm{s}^{-1}$ scan rate.

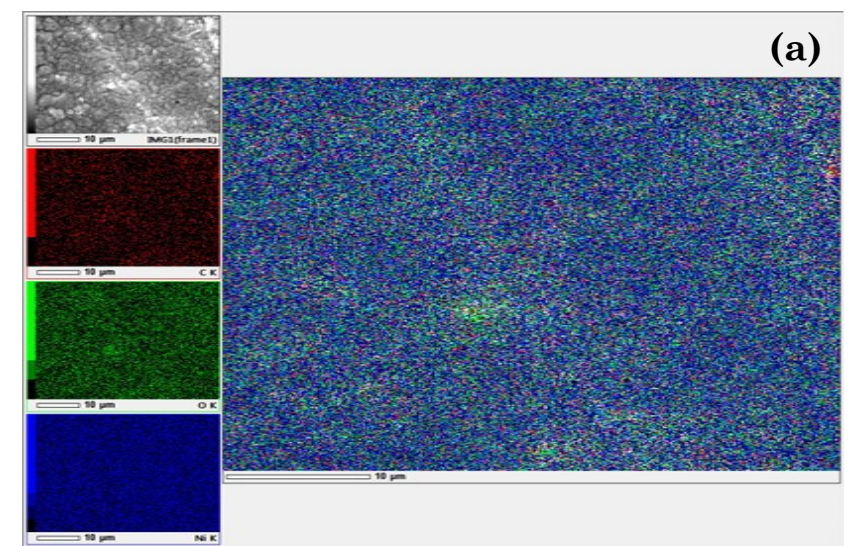

0.382 grams of mass after electrodeposition had proved that $\mathrm{NiO} / \mathrm{Ni}$ has been deposited on the graphite as graphite/NiO/Ni.

Electrochemical catalyst electrode characterization was tested by cyclic voltametric. The electroactive capability of the electrode was an important factor to be tested. The electrocatalytic character of an electrode was measured by oxidation reaction which is indicated by the voltammogram data. The high current re-

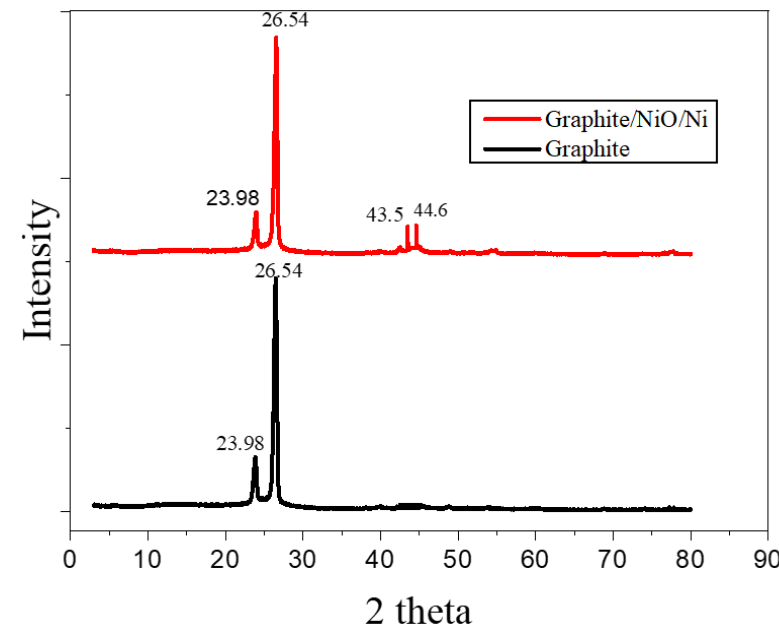

Figure 3. XRD pattern of graphite and graphite/NiO/Ni electrodes.
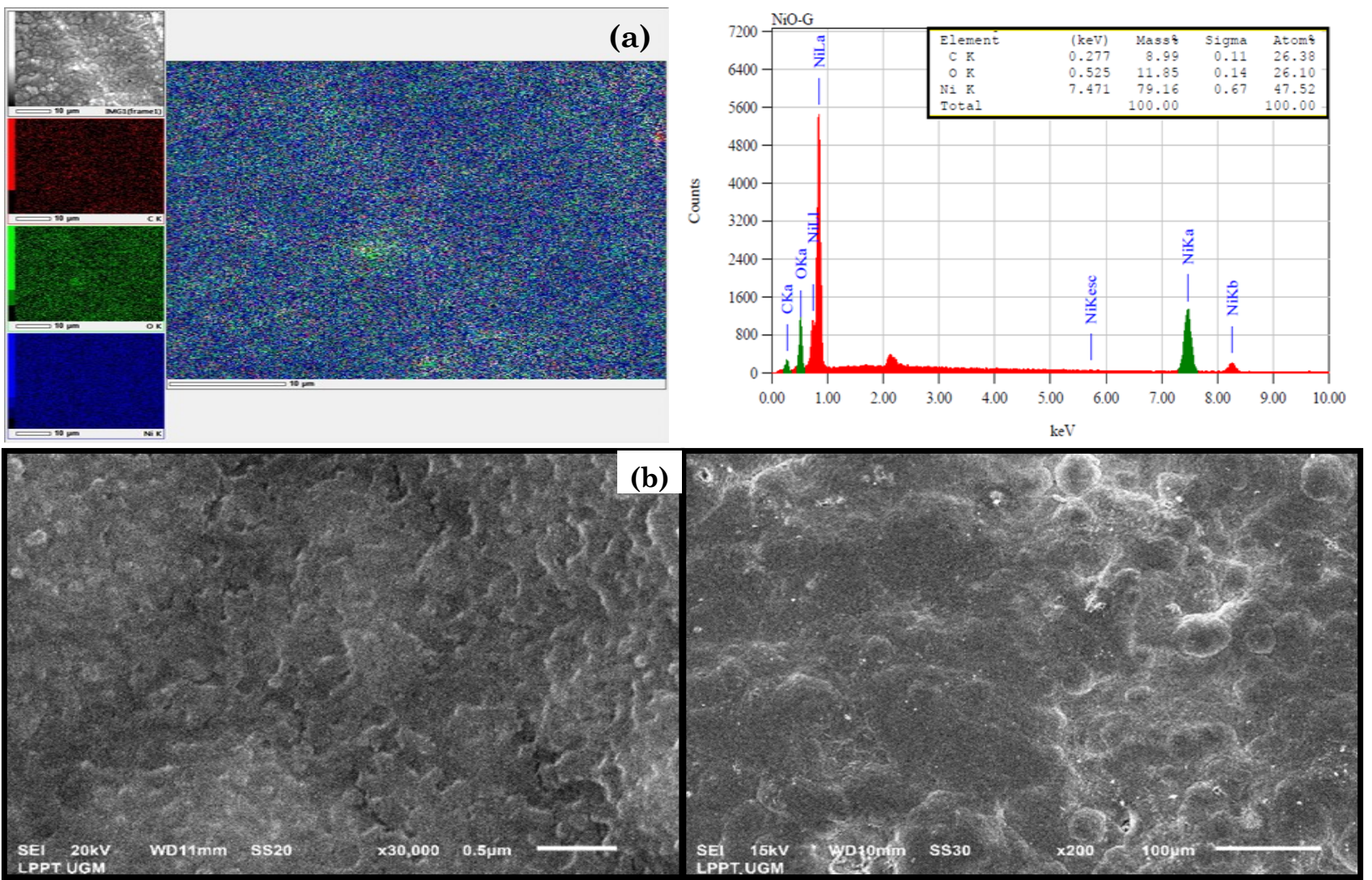

Figure 4. (a) EDX spectrum of graphite/NiO/Ni electrode and (b) SEM images of graphite/NiO/Ni electrode. 
sponse of the voltammogram data shows the ease of the $\mathrm{Cl}^{-}$oxidation reaction by the electrode [27]. Graphite electrode and graphite/NiO/Ni voltammograms data are presented in Figure 2. The voltammogram data in Figure 2 shows that the current response of graphite/NiO/Ni electrode was higher than graphite electrode. This indicated that $\mathrm{Cl}^{-}$oxidation reaction by graphite/ $\mathrm{NiO} / \mathrm{Ni}$ electrodes was easier, hence the electrocatalytic ability of graphite/NiO/Ni electrodes was higher than graphite electrodes.

Testing of the phase composition of the electrode surface was carried out using an XRD instrument. The graphite and graphite/NiO/Ni electrode diffractograms are shown in Figure 3. As shown in Figure 3, the characteristic peak of graphite appeared at $2 \theta=26.54^{\circ}(002)$. Characteristics of graphite appeared at $2 \theta=26.5^{\circ}$ (002), 54.7 $(004)$, and $87.1^{\circ}$ (006) [28]. The XRD diffractogram on graphite/NiO/Ni electrode showed the appearance of two new diffraction peaks at $2 \theta=43.5^{\circ}$ and $44.6^{\circ}$. The XRD spectrum characteristic of $\mathrm{NiO}$ appeared at $2 \theta=37.2^{\circ}(111), 43.3^{\circ}(200), 62.9^{\circ}(220)$, $75.4^{\circ}(220)$, and $79.4^{\circ}$ (311) [29]. Based on Figure 3 , the XRD spectrum of the graphite/NiO/Ni electrode showed that $\mathrm{Ni}$ was deposited on graphite as $\mathrm{NiO}$ at $2 \theta=43.5^{\circ}$. The diffraction peak at $2 \theta=44.6^{\circ}$ in Figure 3 shows the characteristics of Ni (JCPDS No. 70-0989), this indicated that $\mathrm{NiO} / \mathrm{Ni}$ catalyst had been deposited on the graphite electrode as graphite/ $\mathrm{NiO} / \mathrm{Ni}$.

Characterization by SEM-EDX showed that $\mathrm{NiO} / \mathrm{Ni}$ was deposited on the graphite surface. The results of EDX analysis presented in Figure 4 showed that $\mathrm{Ni}$ and $\mathrm{O}$ particles scattered on the graphite surface particles were solid

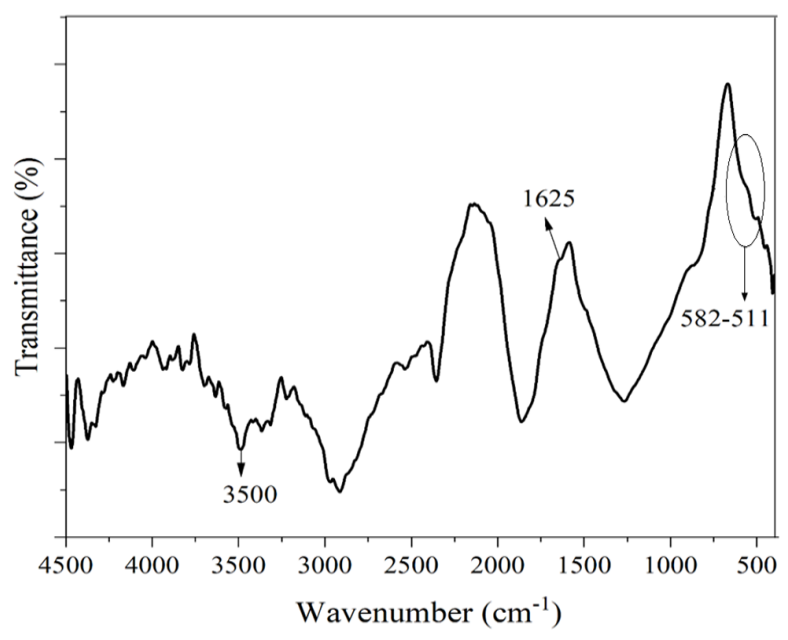

Figure 5. FTIR spectrum of graphite/NiO/Ni electrode. grains and cracks. The same results were also found for $\mathrm{NiO}$ electrodeposits on fluorine doped tin oxide (FTO) glass substrate [23].

FTIR spectra of graphite/ $\mathrm{NiO} / \mathrm{Ni}$ electrodes in 500-4500 $\mathrm{cm}^{-1}$ was shown in Figure 5. Figure 5 shows the appearance of a peak at 3500 $\mathrm{cm}^{-1}$ which indicated stretching $(\mathrm{v})(\mathrm{O}-\mathrm{H})$, $1625 \mathrm{~cm}^{-1}$ indicated bending $(\sigma)(\mathrm{HO}-\mathrm{H})$, and $582-511 \mathrm{~cm}^{-1}$ showed $\delta(\mathrm{Ni}-\mathrm{O})$. Previous research stated that $\delta(\mathrm{Ni}-\mathrm{O})$ occurred between 610 and $480 \mathrm{~cm}^{-1}$ [30], stretching $(\mathrm{v})(\mathrm{O}-\mathrm{H})$ occurred at $3500 \mathrm{~cm}^{-1}$ and bending $(\sigma)(\mathrm{HO}-\mathrm{H})$ appeared at $1625 \mathrm{~cm}^{-1}$ [31].

3.2 The Electro-oxidation of Remazol Black 5 Dye at Various Concentrations of $\mathrm{NaCl}$ Solution

The concentration of $\mathrm{NaCl}$ greatly affects the degradation of remazol black 5 dye. Degradation of remazol black 5 dye occurs in the presence of oxidizing agents $\mathrm{Cl}_{2}, \mathrm{HClO}$, and $\mathrm{ClO}^{-}$. The number of oxidizing agents $\mathrm{Cl}_{2}$, $\mathrm{HClO}$, and $\mathrm{ClO}^{-}$are influenced by the concentration of $\mathrm{NaCl}$. The mechanism of electrochemical degradation in presence of $\mathrm{NaCl}$ is as follows:

Anode reaction $\quad: 2 \mathrm{Cl}^{-} \rightarrow \mathrm{Cl}_{2}+2 \mathrm{e}^{-}$

Cathode reaction $\quad: 2 \mathrm{H}_{2} \mathrm{O}+2 \mathrm{e}^{-} \rightarrow \mathrm{H}_{2}+2 \mathrm{OH}^{-}$(3) Bulk solution reaction: $\mathrm{Cl}_{2}+\mathrm{H}_{2} \mathrm{O} \rightarrow \mathrm{HOCl}+\mathrm{H}^{+}+\mathrm{Cl}^{-}$

Bulk solution reaction: $\mathrm{HOCl} \rightarrow \mathrm{H}^{+}+\mathrm{OCl}^{-}$

Increasing $\mathrm{NaCl}$ concentration will clearly increase the quantity of $\mathrm{Cl}_{2}$ as an oxidizing agent. The quantity of oxidizing agents will be proportional to the degradation rate [15].

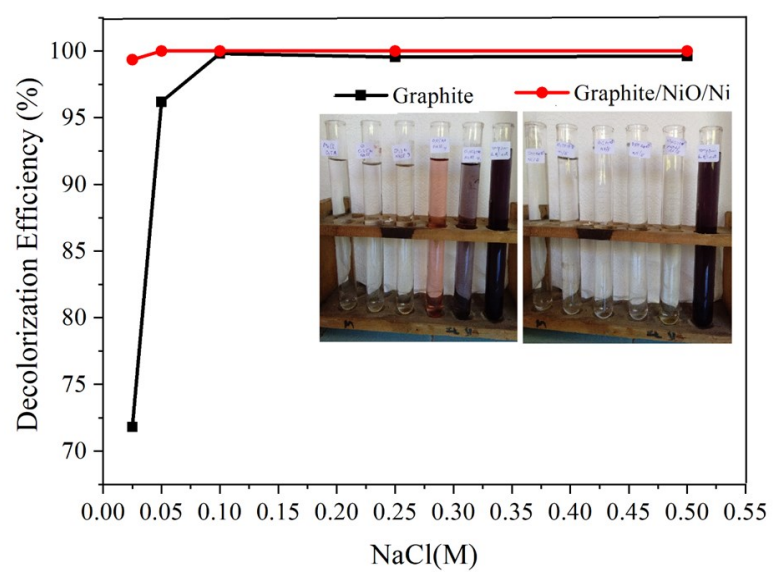

Figure 6. Relation between $\mathrm{NaCl}$ concentration and percentage of the decolorization efficiency 100 ppm of remazol black 5 dye. Insert picture: remazol black 5 dye degradation that is caused by $\mathrm{NaCl}$ concentration in graphite and graphite/ $\mathrm{NiO} / \mathrm{Ni}$. 
Based on Figure 6, an increase in $\mathrm{NaCl}$ solution concentration shows an increase in the decolorization efficiency of remazol black 5 dye. However, at a concentration of $0.1 \mathrm{M} \mathrm{NaCl}$ to $0.5 \mathrm{M} \mathrm{NaCl}$, an increase in remazol black 5 dye decolorization efficiency is not significant, since the $\mathrm{HOCl}$ formed can already degrade most of remazol black 5 dye. Figure 6 shows that the highest decolorization efficiency of remazol black 5 dye for graphite electrode occurred at $0.1 \mathrm{M} \mathrm{NaCl}$ with $99.81 \%$ decolorization efficiency, while the highest decolorization efficiency of remazol black 5 dye for graphite/ $\mathrm{NiO} / \mathrm{Ni}$ electrode occurred at $0.05 \mathrm{M} \mathrm{NaCl}$ with $100 \%$ decolorization efficiency. An increase in $\mathrm{NaCl}$ concentration above the best condition did not influence the efficiency of the decolorization, since almost all remazol black 5 had been degraded. When electrolyte concentration in the degradation process had reached the best condition, the addition of electrolyte concentration did not increase the dye degradation [32]. This means an addition of electrolyte concentration above $0.1 \mathrm{M} \mathrm{NaCl}$ is not necessary since it does not increase the efficiency of the degradation process.

Figure 6 shows that the decolorization efficiency of the graphite/ $\mathrm{NiO} / \mathrm{Ni}$ electrode was $99.35 \%$, while that of the graphite electrode was $71.81 \%$ at $0.025 \mathrm{M} \mathrm{NaCl}$ concentration. With $0.05 \mathrm{M} \mathrm{NaCl}$ concentration, the decolorization efficiency of the graphite electrode was $96.19 \%$, while the decolorization efficiency of the graphite/ $\mathrm{NiO} / \mathrm{Ni}$ electrode was $100 \%$. The electro-oxidation rate of organic pollutants depends on the catalytic activity of the anode

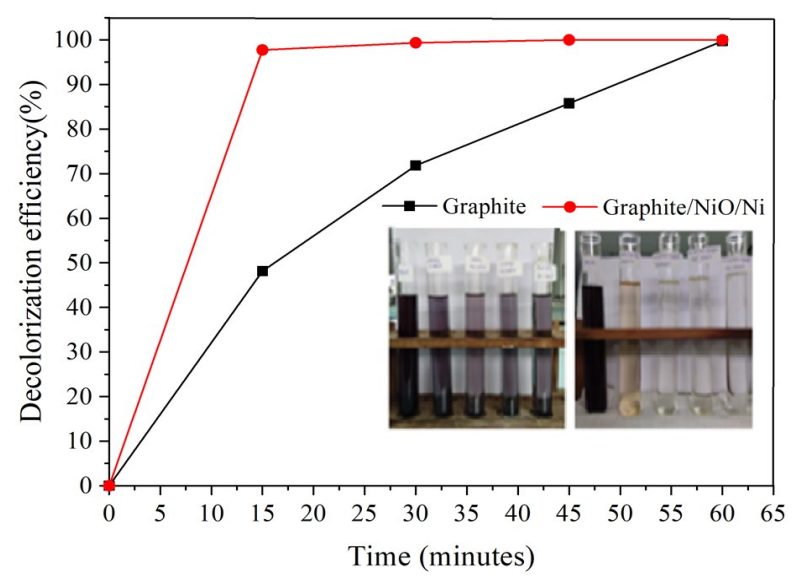

Figure 7. Relation between electro-oxidation time and percentage of the decolorization efficiency $100 \mathrm{ppm}$ of remazol black 5 dye. Insert picture: remazol black 5 dye degradation that is caused by electro-oxidation time in graphite and graphite/NiO/Ni.
[33]. The catalytic activity of the anode can be increased by the addition of a catalyst. Electrocatalysis can improve electrode kinetics by accelerating the half-cell reaction on the electrode surface [34]. Ni is used as an electrocatalyst for anodic and cathodic reactions in organic synthesis and water electrolysis [25]. Based on Figures 2 to $5, \mathrm{NiO} / \mathrm{Ni}$ was deposited on the graphite electrode. The $\mathrm{NiO} / \mathrm{Ni}$ which was deposited on the graphite electrode functioned as an electrocatalyst on the graphite electrode. This caused the decolorization efficiency of graphite/ $\mathrm{NiO} / \mathrm{Ni}$ electrodes to be higher than that of graphite electrodes. Previous research indicated that deposition of oxide $\mathrm{ZnO}-\mathrm{TiO}_{2}$ on graphite felt $(\mathrm{GrF})$ can increase the degradation yield of amido black 10B dye. Electrooxidation of Amido Black 10B dye with GrF$\mathrm{ZnO}-\mathrm{TiO}_{2}$ electrode showed that the degradation results reached $98 \%$ after 70 minutes of electro-oxidation process, which was higher than that of the graphite electrode at $35 \%$ [2].

3.3 Electro-oxidating Remazol Black 5 Dye at Various Electro-oxidation Time

The electro-oxidation process of remazol black 5 dye by graphite and graphite/NiO/Ni electrodes in $\mathrm{NaCl}$ solution occurs through two mechanisms, namely a direct mechanism and an indirect mechanism. Indirect electrooxidation of remazol black 5 dye was done by the $\mathrm{OCl}^{-}$ion, like Equation 5. The indirect reaction of remazol black 5 dye degradation is as follows:

$$
\mathrm{Dye}+\mathrm{OCl}^{-} \rightarrow \mathrm{CO}_{2}+\mathrm{H}_{2} \mathrm{O}+\mathrm{Cl}^{-}
$$

The mechanism of direct pollutant degradation in the electro-oxidation process has several stages. Pollutant $\left(\mathrm{MO}_{\mathrm{x}}\right)$ in water forms $\mathrm{MO}_{\mathrm{x}}(\mathrm{HO} \cdot)$ radical (Equation 7$)$. The radical then changes into $\mathrm{MO}_{\mathrm{x}+1}$ (Equation 8) and releases oxygen (Equation 9). $\mathrm{MO}_{\mathrm{x}+1}$ undergoes a further reaction and produces oxygen like in Equation 10. Furthermore, the radical $\mathrm{MO}_{\mathrm{x}}(\mathrm{HO} \cdot)$ and $\mathrm{MO}_{\mathrm{x}+1}$ oxidize organic pollutants (Equations (11 and 12)). All of the processes occur catalytically on the anode surface according to Equations (9-12).

$$
\begin{aligned}
& \mathrm{MO}_{\mathrm{x}}+\mathrm{H}_{2} \mathrm{O} \rightarrow \mathrm{MO}_{\mathrm{x}}(\mathrm{HO} \cdot)+\mathrm{H}^{+}+\mathrm{e}^{-} \\
& \mathrm{MO}_{\mathrm{x}}(\mathrm{HO} \cdot) \rightarrow \mathrm{MO}_{\mathrm{x}+1}+\mathrm{H}^{+}+\mathrm{e}^{-} \\
& \mathrm{MO}_{\mathrm{x}}(\mathrm{HO} \cdot) \rightarrow \mathrm{MO}_{\mathrm{x}}+\mathrm{H}^{+}+\mathrm{e}^{-}+1 / 2 \mathrm{O}_{2} \\
& \mathrm{MO}_{\mathrm{x}+1} \rightarrow \mathrm{MO}_{\mathrm{x}}+1 / 2 \mathrm{O}_{2} \\
& \mathrm{MO}_{\mathrm{x}}(\mathrm{HO} \cdot)+\mathrm{RH} \rightarrow \mathrm{MO}_{\mathrm{x}}+\mathrm{H}_{2} \mathrm{O}+\mathrm{R} \\
& \mathrm{MO}_{\mathrm{x}+1}+\mathrm{RH} \rightarrow \mathrm{MO}_{\mathrm{x}}+\mathrm{RHO}
\end{aligned}
$$


Overall, the electro-oxidation process was directly degraded by the adsorbed hydroxyl radicals generated from the water oxidation reaction [35].

Figure 7 shows that the percentage of remazol black 5 dye decolorization efficiency increases by increasing electro-oxidation time because more hypochlorite ions $\left(\mathrm{OCl}^{-}\right)$and hydroxyl radicals $(\cdot \mathrm{OH})$ are formed. The hypochlorite ion and hydroxyl radicals act as the main oxidizing agents in dye degradation [36]. Figure 7 shows that after 15 minutes of electro-oxidation process, the graphite electrode decolorization efficiency was $48.13 \%$ and that of graphite/NiO/Ni electrode was $97.75 \%$. The highest decolorization efficiency of remazol black 5 dye using graphite $/ \mathrm{NiO} / \mathrm{Ni}$ electrodes was $100 \%$ and the electro-oxidation process lasted for 45 minutes. While at the graphite electrode, the highest decolorization efficiency of remazol black 5 dye was $99.74 \%$ and the electrooxidation process lasted for 60 minutes. The de-
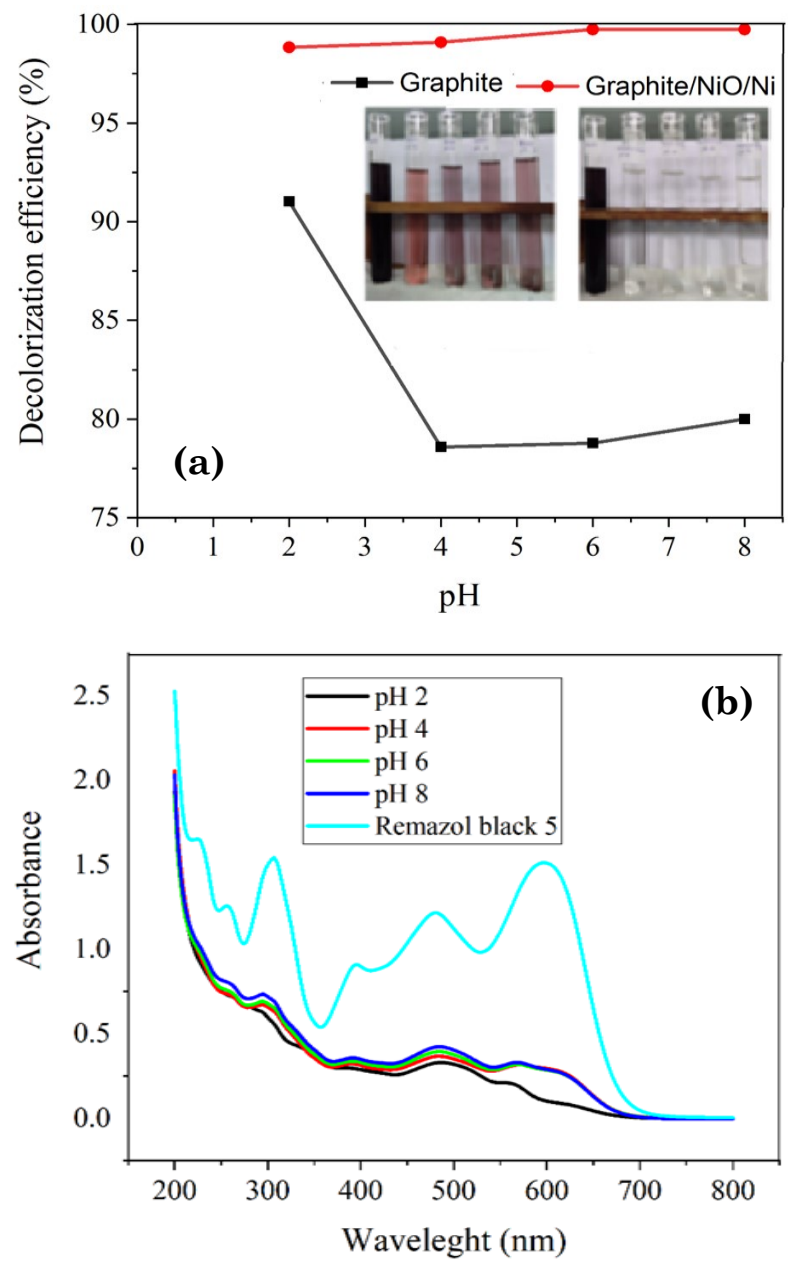

colorization efficiency of the graphite/ $\mathrm{NiO} / \mathrm{Ni}$ electrode was higher than the graphite electrode because $\mathrm{NiO} / \mathrm{Ni}$ electrocatalyst was deposited on the graphite. The $\mathrm{NiO} / \mathrm{Ni}$ electrocatalyst increased the ability of the electrode to oxidize $\mathrm{Cl}^{-}$to be $\mathrm{Cl}_{2}$ (Equation 2), hence accelerated the reaction of Equations 4 - 5 and automatically increased the decolorization efficiency of the remazol black 5 dye (Equation 6). A previous study on the electrochemical oxidation of methylene blue (MB) using stainless steel graphene hydroxyl (SS/G-OH) electrode in $\mathrm{NaCl}$ electrolyte showed that the $\mathrm{MB}$ concentration decreased by $>99 \%$ after 30 minutes of electrolysis [7].

\subsection{Electro-oxidation of Remazol Black 5 Dye} at Various $\mathrm{pH}$

The acidity of the solution affects the performance of the electro-oxidation process. In the electro-oxidation process, chloride ions are used as a supporting electrolyte to produce active chlorine $\left(\mathrm{Cl}_{2}, \mathrm{HOCl}\right.$, and $\left.\mathrm{ClO}^{-}\right)$. The active chlorine depends on the $\mathrm{pH}$ of the solution. The active chlorine in the $\mathrm{pH}$ range of 3-8 is $\mathrm{HClO}$, $\mathrm{ClO}^{-}$in $\mathrm{pH}>8$, and $\mathrm{Cl}_{2(\mathrm{aq})}$ in $\mathrm{pH}$ close to 3 . The standard potential of each active chlorine are $\mathrm{Cl}_{2 \text { (aq) }}\left(\mathrm{E}^{\circ}=1.36 \mathrm{~V} / \mathrm{SHE}\right), \mathrm{HClO}\left(\mathrm{E}^{\circ}=1.49\right.$ $\mathrm{V} / \mathrm{SHE})$, and $\mathrm{ClO}^{-}\left(\mathrm{E}^{\circ}=0.89 \mathrm{~V} / \mathrm{SHE}\right)$ [11].

Based on Figure 8, the highest decolorization efficiency for graphite electrodes was found $91.03 \%$ at $\mathrm{pH} 2$, while for graphite $/ \mathrm{NiO} / \mathrm{Ni}$ electrodes was found $99.74 \%$ at $\mathrm{pH}$ 6 . When the $\mathrm{pH}$ is 2 , the main active chlorine is $\mathrm{Cl}_{2}$. The amount of $\mathrm{Cl}_{2}$ formed exceeds its solubility so that it forms bubbles. It may be partially diffused away from the anode to react

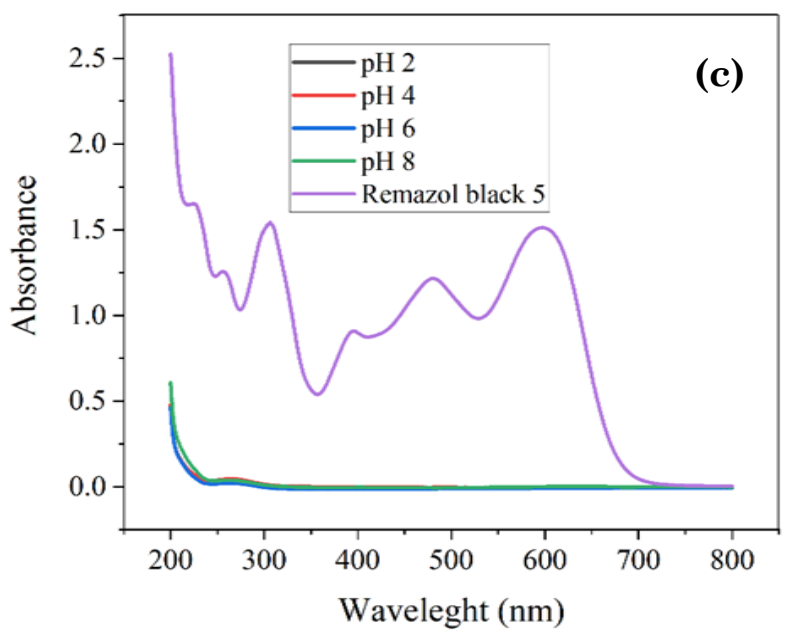

Figure 8. (a) Relation between $\mathrm{pH}$ and percentage of the decolorization efficiency $100 \mathrm{ppm}$ of remazol black 5 dye. Insert picture: remazol black 5 dye degradation that is caused by various $\mathrm{pH}$ in graphite and graphite/ $\mathrm{NiO} / \mathrm{Ni}$, (b) the absorbance spectra of the graphite electrode, (c) the absorbance spectra of the graphite/ $\mathrm{NiO} / \mathrm{Ni}$ electrode. 
with other chlorides, forming trichloride or hypochlorous acid, and chloride ions [37]. As a result of this incident, not all of the chlorine formed degraded remazol black 5, so the decolorization efficiency of $\mathrm{pH} 2$ was lower than $\mathrm{pH}$ 6 even though it had a higher $\mathrm{E}^{\circ} \mathrm{Cl}_{2}$ than $\mathrm{E}^{\circ}$ $\mathrm{ClO}^{-}$. At $\mathrm{pH} 6$ the main active chlorine is $\mathrm{HOCl}$. HOCl is not affected by gas desorption at the anode, so the decolorization efficiency of remazol black 5 dye was higher than $\mathrm{pH} 2$. In addition, the decolorization efficiency of graphite/ $\mathrm{NiO} / \mathrm{Ni}$ electrode was higher than graphite, because there were $\mathrm{NiO}$ and $\mathrm{Ni}$ deposited on graphite, as shown in Figures 2 to 5 . $\mathrm{NiO}$ and $\mathrm{Ni}$ acted as electrocatalysts that could accelerate the electro-oxidation reaction of remazol black 5 . The results of a similar study stated that $\mathrm{pH} 5.49$ was the best for the electrooxidation of textile waste which used $\mathrm{Ti} / \mathrm{RuO}_{2}$ anodes [17] and $\mathrm{pH} 4$ was the best for degrading 96\% reactive blue $109(1000 \mathrm{mg} / \mathrm{L})$ with $\mathrm{Pt}$ anode electrode at current (I) $20 \mathrm{~mA} / \mathrm{cm}^{2}, 0.1 \mathrm{M}$ $\mathrm{NaCl}$ [19].

Figures 8(b) and 8(c) show the spectra of remazol black 5 before and after electrooxidation. The spectra of remazol black 5 before electro-oxidation showed six bands, namely $595,558,391,310,254$, and $229 \mathrm{~nm}$. Two are in the visible region (595 and $558 \mathrm{~nm}$ ) and the others are in the ultraviolet region $(229,254$, 310 , and $391 \mathrm{~nm}$ ). Previous research stated that remazol black 5 spectra showed 5 spectra bands, namely one in the visible region (595 $\mathrm{nm})$ and others in the ultraviolet region (229, 254, 310, and $391 \mathrm{~nm}$ ) [3]. The peak at $595 \mathrm{~nm}$ is the characteristic of the chromophoric azo group $(-\mathrm{N}=\mathrm{N}-)$, while the peaks at 254 and 310 $\mathrm{nm}$ are associated with benzene and naphthalene rings [3,37]. Figure 8 shows all the decreasing peaks during the electro-oxidation process. The decreasing peak at $595 \mathrm{~nm}$ indicated that the chomophoric azo group could be easily electro-oxidized. On the other hand, the decrease in absorbance in the UV region was lower, because the aromatic structure was more stable than the chromophoric azo group. The decrease in absorbance spectra for graphite/NiO/Ni electrodes (Figure $8(\mathrm{a})$ ) is greater than that for graphite electrodes (Figure 8(b)); this is caused by the $\mathrm{NiO} / \mathrm{Ni}$ electrocatalyst. The NiO/Ni electrocatalyst has improved the performance of graphite electrodes in the remazol black 5 dye electro-oxidation process. Remazol black 5 dye electrodes may lead to the formation of intermediates. This intermediate accelerates the decrease in absorbance at $595 \mathrm{~nm}$ by removing the chromophoric azo group before the aliphatic carboxylic acid and carbon dioxide are formed [38].

\section{Conclusion}

$\mathrm{NiO} / \mathrm{Ni}$ electrocatalyst has been successfully deposited on graphite electrodes by electrodeposition. $\mathrm{NiO} / \mathrm{Ni}$ electrocatalyst has improved the performance of graphite electrodes in remazol black 5 electro-oxidation. The best $\mathrm{NaCl}$ concentration for remazol black 5 electrooxidation was $0.05 \mathrm{M}$ for graphite $/ \mathrm{NiO} / \mathrm{Ni}$ and $0.1 \mathrm{M}$ for graphite with $100 \%$ and $99.81 \%$ decolorization efficiency, respectively. The best time for remazol black 5 electro-oxidation was 45 minutes for graphite $/ \mathrm{NiO} / \mathrm{Ni}$ and 60 minutes for graphite with $100 \%$ and $99.74 \%$ decolorization efficiency, respectively. While, the best $\mathrm{pH}$ for the remazol black 5 electrooxidation was $\mathrm{pH} 6$ for graphite/ $\mathrm{NiO} / \mathrm{Ni}$ and $\mathrm{pH}$ 2 for graphite with $99.74 \%$ and $91.03 \%$ decolorization efficiency, respectively. Graphite/ $\mathrm{NiO} / \mathrm{Ni}$ electrodes have good prospects to be developed as electrodes to degrade textile waste.

\section{Acknowledgment}

This research was supported by the Directorate General of Resources for Science, Technology, and Higher Education under the Ministry of Research and Higher Education through the BPPNDN S3 scholarship; Chemistry Department, FMIPA Universitas Gadjah Mada; and Chemistry Department, FMIPA Universitas Pendidikan Ganesha.

\section{References}

[1] Kenova, T.A., Kornienko, G.V., Golubtsova, O.A., Kornienko, V.L., Maksimov, N.G. (2018). Electrochemical Degradation of Mordant Blue 13 Azo Dye Using Boron Doped Diamond and Dimensionally Stable Anodes: Influence of Experimental Parameters and Water Matrix. Environmental Science and Pollution Research, 25(30), 30425-30440. DOI: 10.1007/s11356-018-2977-z.

[2] El-Kacemi, S., Zazou, H., Oturan, N., Dietze, M., Hamdani, M., Es-Souni, M., Oturan, M.A. (2017). Nanostructured ZnO-TiO2 Thin Film Oxide as Anode Material in Electrooxidation of Organic Pollutants. Application to The Removal of Dye Amido Black 10B from Water. Environmental Science and Pollution Research, 24(2), 1442-1449. DOI: 10.1007/s11356-016-7920-6. 
[3] Droguett, T., Gomes, J.M., Gabaldon, M.G., Ortega, E., Mestre, S., Cifuentes, G., Herranz, V.P. (2020). Electrochemical Degradation of Reactive Black 5 Using Two-different Reactor Configuration. Scientific Reports, 10(1), 1-11. DOI: $10.1038 / \mathrm{s} 41598-020-61501-5$.

[4] Rahmadyanti, E., Febriyanti, C.P. (2020). Feasibility of Constructed Wetland Using Coagulation Flocculation Technology in Batik Wastewater Treatment. Journal of Ecological Engineering, 21(6), 67-77. DOI: $10.12911 / 22998993 / 123253$.

[5] Joe, J., Kothari, R.K., Raval, C.M., Kothari, C.R. (2011). Decolorization of Textile Dye Remazol Black B by Pseudomonas Aeruginosa CR-25 Isolated from The Common Effluent Treatment Plant. Journal of Bioremediation \& Biodegradation, 02(02), 2-6. DOI: 10.4172/2155-6199.1000118.

[6] Sulistiyo, Y.A., Andriana, N., Piluharto, B., Zulfikar, Z. (2017). Silica Gels from Coal Fly Ash as Methylene Blue Adsorbent: Isotherm and Kinetic Studies. Bulletin of Chemical Reaction Engineering \& Catalysis, 12(2), 263272. DOI: $10.9767 /$ bcrec.12.2.766.263-272.

[7] Yusbarina, Y., Roto, R., Triyana, K. (2021). Hydroxyl Functionalized Graphene As a Superior Anode Material for Electrochemical Oxidation of Methylene Blue. Rasayan Journal of Chemistry, 14(2), 1140-1147. DOI: 10.31788/rjc.2021.1426180.

[8] Kaur, P., Sangal, V.K., Kushwaha, J.P. (2015). Modeling and Evaluation of ElectroOxidation of Dye Wastewater Using Artificial Neural Networks. Royal Society of Chemistry Advances, 5(44), 34663-34671. DOI: 10.1039/c4ra14160a.

[9] Jager, D., Kupka, D., Vaclavikova, M., Ivanicova, L., Gallios, G. (2018). Degradation of Reactive Black 5 by Electrochemical Oxidation. Chemosphere, 190, 405-416. DOI: 10.1016/j.chemosphere.2017.09.126.

[10] Migliorini, F.L., Steter, J.R., Rocha, R.S., Lanza, M.R.V., Baldan M.R., Ferreira, N.G. (2016). Efficiency Study and Mechanistic Aspects in The Brilliant Green Dye Degradation Using BDD/Ti Electrodes. Diamond \& Related Materials, 65, 5-12. DOI: 10.1016/j.diamond.2015.12.013.

[11] Brillas, E., Martínez-Huitle, C.A. (2015). Decontamination of Wastewaters Containing Synthetic Organic Dyes by Electrochemical Methods. An Updated Review. Applied Catalysis B: Environmental, 166-167, 603-643. DOI: $10.1016 /$ j.apcatb.2014.11.016.
[12] Sirés, I., Brillas, E., Oturan, M.A., Rodrigo, M.A., Panizza, M. (2014). Electrochemical Advanced Oxidation Processes: Today and Tomorrow. A Review. Environmental Science and Polluttion Research, 21(14), 8336-8367. DOI: $10.1007 / \mathrm{s} 11356-014-2783-1$.

[13] Martínez-Huitle, C.A., Dos Santos, E.V., De Araújo, D.M., Panizza, M. (2012). Applicability of Diamond Electrode/Anode to The Electrochemical Treatment of a Real Textile Effluent. Journal of Electroanalytical Chemis-

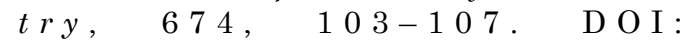
10.1016/j.jelechem.2012.02.005.

[14] Särkkä, H., Bhatnagar, A., Sillanpää, M. (2015). Recent Developments of Electrooxidation in Water Treatment. A Review. Journal of Electroanalytical Chemistry, 754, 46-56. DOI: 10.1016/j.jelechem.2015.06.016.

[15] Moreira, F.C., Boaventura, R.A.R., Brillas, E., Vilar, V.J.P. (2017). Electrochemical Advanced Oxidation Processes: A Review on Their Application to Synthetic and Real Wastewaters. Applied Catalysis B: Environmental, 202, 217-261. DOI: 10.1016/j.apcatb.2016.08.037.

[16] Oturan, M.A., Aaron, J.J. (2014). Advanced Oxidation Processes in Water/Wastewater Treatment: Principles and Applications. A Review. Critical Reviews in Environmental Science and Technology, 44(23), 2577-2641. DOI: $10.1080 / 10643389.2013 .829765$.

[17] Kaur, P., Kushwaha, J.P., Sangal, V.K. (2017). Evaluation and Disposability Study of Actual Textile Wastewater Treatment by Electro-oxidation Method Using Ti/RuO2 Anode. Process Safety and Environmental Prote ction, $111, \quad 13-22$. D O I : 10.1016/j.psep.2017.06.004.

[18] Peleyeju, M.G., Umukoro, E.H., Babalola, J.O., Arotiba, O.A. (2015). Electrochemical Degradation of an Anthraquinonic Dye on an Expanded Graphite-Diamond Composite Electrode. Electrocatalysis, 7(2), 132-139. DOI: $10.1007 / \mathrm{s} 12678-015-0291-9$

[19] Nordin, N., Amir, S.F.M., Riyanto, Othman, M.R. (2013). Textile Industries Wastewater Treatment by Electrochemical Oxidation Technique Using Metal Plate. International Journal of Electrochemical Science, 8(9), 11403-11415.

[20] Alaoui, A., El Kacemi, K., El Ass, K., Kitane, S., El Bouzidi, S. (2015). Activity of Pt/MnO2 Electrode in The Electrochemical Degradation of Methylene Blue in Aqueous Solution. Separation and Purification Technology, 154, 281-289. DOI: 10.1016/j.seppur.2015.09.049. 
[21] Shestakova, M., Sillanpää, M. (2017). Electrode Materials Used for Electrochemical Oxidation of Organic Compounds in Wastewater. Reviews in Environmental Science and Biotechnology, 16(2), 223-238. DOI: 10.1007/s11157-017-9426-1.

[22] Nidheesh, P.V., Gandhimathi, R. (2014). Removal of Rhodamine B from Aqueous Solution Using Graphite-graphite Electro-Fenton System. Desalination and Water Treatment, 52, $10-12, \quad 1872-1877$. D O I : 10.1080/19443994.2013.790321.

[23] Basharat, F., Rana, U.A., Shahid, M., Serwar, M. (2015). Heat Treatment of Electrodeposited NiO Films for Improved Catalytic Water Oxidation. RSC Advances, 5(105), 8671386722. DOI: 10.1039/c5ra17041a.

[24] Dar, F.I., Moonooswamy, K.R., Es-Souni, M. (2013). Morphology and Property Control of $\mathrm{NiO}$ Nanostructures for Supercapacitor Applications. Nanoscale Research Letters, 8(1), 1-7. DOI: 10.1186/1556-276X-8-363.

[25] Döner, A., Telli, E., Kardaş, G. (2012). Electrocatalysis of Ni-Promoted Cd Coated Graphite Toward Methanol Oxidation in Alkaline Medium. Journal of Power Sources, 205, 7179. DOI: 10.1016/j.jpowsour.2012.01.020.

[26] Zhang, J., Zhang, D., Liu, Y. (2019). Ni-SiO2 Nanoporous Composite as an Efficient Electrocatalyst for the Electrooxidation of Hydrogen Peroxide. Journal of Materials Science: Materials in Electronic, 30(15), 13895-13909. DOI: 10.1007/s10854-019-01707-0.

[27] Mukimin, A., Vistanty, H., Zen, N. (2015). Oxidation of Textile Wastewater Using Cylinder $\mathrm{Ti} / \beta-\mathrm{PbO}_{2}$ Electrode in Electrocatalytic Tube Reactor. Chemical Engineering Journal, 259, 430-437. DOI: 10.1016/j.cej.2014.08.020.

[28] Popova, A.N. (2017). Crystallographic Analysis of Graphite by X-Ray Diffraction. Coke and Chemistry, 60(9), 361-365. DOI: 10.3103/S1068364X17090058.

[29] Fan, M., Ren, B., Yang, X., Yu, H., Wang, L. (2019). NiO@NiO and $\mathrm{NiO} @ \mathrm{Co}_{3} \mathrm{O}_{4}$ Hollow Core/Shell Composites for High-Performance Supercapacitor Electrodes. Journal of Nanoscience and Nanotechnology, 19(12), 77857789. DOI: 10.1166/jnn.2019.16857.

[30] Rebelo, Q.H.F., Ferreira, C.S., Santos, P.L., Bonacin, J.A., Passos, R.R., Pocrifka, L.A., Paula, M.M.S. (2019). Synthesis and Characterization of a Nanocomposite $\mathrm{NiO} / \mathrm{SiO}_{2}$ from a Sustainable Source of $\mathrm{SiO}_{2}$. Particulate Science and Technology, 37(8), 907-911. DOI: 10.1080/02726351.2018.1455781.
[31] Azaceta, E., Chavhan, S., Rossi, P., Paderi, M., Fantini, S., Ungureanu, M., Miguel, O., Grande, H.J., Tena-Zaera, R. (2012). NiO Cathodic Electrochemical Deposition from an Aprotic Ionic Liquid: Building Metal Oxide NP Heterojunctions. Electrochimica Acta, 71, 39-43. DOI: 10.1016/j.electacta.2012.03.093.

[32] Kariyajjanavar, P., Jogttappa, N., Nayaka, Y.A. (2011). Studies on Degradation of Reactive Textile Dyes Solution by Electrochemical Method. Journal of Hazardous Materials, $190(1-3), \quad 952-961$. D O I : 10.1016/j.jhazmat.2011.04.032.

[33] Hajji, M., Baddouh, A., Rghuiti, M., Jbara, O., Tara, A., Bazzi, L., Benlhachemi, A., Hilali, M. (2015). Electrochemical Degradation of Some Organic Dyes by Electrochemical Oxidation on a Ti/ $\mathrm{Cu}_{2} \mathrm{O}$ Electrode. Applied Journal of Environmental Engineering Science, 1(1), 1-8. DOI: 10.5004/dwt.2011.1926

[34] Patel, P.S., Bandre, N., Saraf, A., Ruparelia, J.P. (2013). Electro-Catalytic Materials (Electrode Materials) in Electrochemical Wastewater Treatment. Procedia Engineer$i n g, \quad 51, \quad 430-435$. D O I : 10.1016/j.proeng.2013.01.060.

[35] Nidheesh, P.V., Zhou, M., Oturan, M.A. (2018). An overview on The Removal of Synthetic Dyes from Water by Electrochemical Advanced Oxidation Processes. Chemosphere, $197, \quad 210-227 . \quad$ D O I : 10.1016/j.chemosphere.2017.12.195.

[36] Morsi, M.S., Al-Sarawy, A.A., Shehab ElDein, W.A. (2011). Electrochemical Degradation of Some Organic Dyes by Electrochemical Oxidation on a $\mathrm{Pb} / \mathrm{PbO} 2$ Electrode. Desalination and Water Treatment, 26, 301-308. DOI: 10/5004/dwt.2011.1926.

[37] Gautam, R.K., Chattopadhyaya, M.C. (2016). Advanced Nanomaterials for Wastewater Remediation. Publisher: CRC Press. DOI: 10.1201/9781315368108-4

[38] Rivera, M., Pazos, M., Sanromán, M.Á. (2011). Development of an Electrochemical Cell for The Removal of Reactive Black 5. Desalination, 274 (1-3), 39-43. DOI: 10.1016/j.desal.2011.01.074. 